Unnati Bihola, Prajesh Prajapati* and Y. K. Agrawal

\title{
HPLC - Quality by Design Approach for Simultaneous Detection of Torsemide, Spironolactone and Their Degradant Impurities
}

https://doi.org/10.1515/pthp-2018-0011

Received March 13, 2018; revised April 23, 2018; accepted April 23, 2018

\begin{abstract}
A simple, highly robust (quality by design (QbD) approach), precise and accurate method using high performance liquid chromatography coupled to mass spectrometry has been established for the simultaneous separation, identification and quantitation of a Torsemide (TOR), spironolactone (SPI) and their degradant impurities. The chromatographic separations of drugs and impurities were achieved on a inertsil ODS$3 \mu \mathrm{m} \mathrm{C} 18,150 \mathrm{~mm} \times 4.6 \mathrm{~mm}$, while the isocratic elution using a ternary mobile phase mixture of methanol, acetonitrile and water $(5: 3: 2 \mathrm{v} / \mathrm{v} / \mathrm{v})$ at a flow rate of $0.2 \mathrm{~mL} /$ min was adopted for achieving optimum separations. The quantitation of torsemide and spironolactone was accomplished by UV detection at $254 \mathrm{~nm}$ and identification of the degradants were done by comparing identical mass in mass spectrometer. The recoveries of the torsemide and spironolactone were obtained higher than $98 \%$ with good validation parameters; linearity $(\mathrm{r} 2>0.994)$, LOD and LOQ was 10 and $33 \mathrm{ng}$ for TOR and 75 and $248 \mathrm{ng}$ for SPI respectively. The quality by design (QbD) approach has been successfully utilized to prove the method is robust even deliberate changes in critical parameters.
\end{abstract}

Keywords: Quality by Design, HPLC, Torsemide, Spironolactone, Degradant Impurity

\section{Introduction}

Torsemide (TOR) and Spironolactone (SPI) (Figure 1) are most widely used drug for treatment of diurectics [1].

*Corresponding author: Prajesh Prajapati, Institute of Research and Development, Gujarat Forensic Sciences University, Sector-9, Nr. Police bhavan, Gandhinagar 382007, Gujarat, India,

E-mail: prajeshprajapati@gmail.com

Unnati Bihola, Y. K. Agrawal, Institute of Research and Development, Gujarat Forensic Sciences University, Sector-9, Nr. Police bhavan, Gandhinagar 382007, Gujarat, India
A safe, reliable and accurate method has to be incorporated to find out the concentration of these drugs simultaneously as they are available in combined as well as single dosage.

Extended review reveals that various analytical methods based on spectrophotometric [2-8], HPLC [9-20], HPTLC [21], LC-ESI-MS [22] have been developed for determination of TOR in pharmaceutical dosage forms and biological fluids or in combination with other drugs [5-8, 18-20]. Extended review reveals that various analytical methods based on spectrophotometric [23-34, 36], HPLC [22-24, 37-39, 41, 42], HPTLC [9, 43, 44, 44-46], HPLCAPCI-MS [27], UPLC [47], LC [48] have been developed for determination of SPI in pharmaceutical dosage forms and biological fluids or in combination with other drugs [28-48] and also Reported Method for TOR and SPI Combination [49-55]. The design space covering the influences of various factors was still to be generated for HPLC method. So it was thought proper to use this combination for the present study for development of QbD (Quality by Design) based HPLC method. Several methods viz. HPLC and MS are reported for the stability of the TOR and SPI and acid degradation products $[56,57]$. Although, there were lots of method available, we have developed simple, accurate and precise method using LC/MS for identification and detection of degradants of the TOR and SPI. The main advantage of this paper is to analyse simultaneously API and its degradants.

\section{Materials and methods}

\section{Instruments}

\section{HPLC chromatograph}

A GL Science (USA) HPLC chromatograph was used for the separations in this study. It was equipped with binary pump, which were capable to adjust the flow rate $(0.01$ to $5 \mathrm{~mL} / \mathrm{min}$.). It is also equipped with an Autosampler with a capacity of accurately injecting the 
<smiles>CC(=O)SC1CC2=CC(=O)CC[C@]2(C)[C@H]2CC[C@]3(C)[C@@H](CC[C@]34CCC(=O)O4)[C@@H]12</smiles>

Figure 1: Molecular structure of (a) Torsemide (TOR) and (b) Spironolactone (SPI). sample volume of $50 \mathrm{~nL}$ to $100 \mu \mathrm{L}$ into the analytical column. The analytes were detected by using fibre optics based UV detector. The effluent coming from the HPLC was injected in the MS/MS for detection of any impurity if present.

\section{Mass spectrometer}

An AB Sciex (Canada) QTRAP-4500 series mass spectrometer was used in the present investigation. It was equipped with linear trap technology and contain TurboV ${ }^{\mathrm{TM}}$ source which provides high level of sensitivity with low volume flow rates. The TurboV chamber has two turbo heaters which will improved gas dynamics and helps in ionization. The analyst software was used to perform data acquisition and integration.

\section{LC/MS conditions}

Silica column (Inertsil ODS-3 $\mu \mathrm{m} \mathrm{C18}, 150 \mathrm{~mm} \times 4.6 \mathrm{~mm}$ ) protected by precolumn filter cartridges, was used to analyze the samples. After optimization, mobile phase consisting of Acetonitrile: Methanol: Water (5:3:2 v/v/v) was used at flow rate of $0.2 \mathrm{~mL} / \mathrm{min}$. The optimized value for MS/MS analyses were as follows: ESI positive ion mode; capillary voltage, $5500 \mathrm{eV}$; cone voltage, $40 \mathrm{~V}$; Gas 1 (nebulizing gas) and Gas 2 (drying gas) were set to 40 units and 20 units respectively and the source temperature was set at $650^{\circ}$. Mechanically dried air was used as Nebulizing and drying gas. The injection volume and column temperature were set at $10 \mu \mathrm{L}$ and $40^{\circ} \mathrm{C}$, respectively. Full scan LC-MS spectra were obtained by scanning from $\mathrm{m} / \mathrm{z} 50$ to 500 . The LC was connected to the mass spectrometer and effluent was injected for detection of impurities if present.

\section{Materials}

TOR and SPI standard were obtained as gift specimen from Macleods Pharma Pvt. Ltd (Mumbai, India) and tablet containing TOR and SPI were procured from local market. Acetonitrile (HPLC Grade), methanol (HPLC Grade), water (distilled) - and whatmann filter paper no. $42(0.45 \mu \mathrm{m})$ were used.

\section{Method}

\section{Selection of analytical wavelength}

The spectra taken at $\lambda_{\max } 254 \mathrm{~nm}$ of TOR and SPI in the mobile phase was found to be linear and degraded products were well separated. So $254 \mathrm{~nm}$ of TOR and SPI were chosen as detection wavelength in HPLC.

\section{Preparation of mobile phase}

The mixture of $30 \mathrm{~mL}$ methanol, $50 \mathrm{~mL}$ acetonitrile, $20 \mathrm{~mL}$ water was filtered through $0.45 \mu \mathrm{m}$ filter paper and the blend was sonicated for $10 \mathrm{~min}$ to degas the mixture and used as mobile phase.

\section{Forced degradation studies}

The stress degradation studies were carried out as reported $[58,59]$. Standard drug samples have been dissolved in $0.5 \mathrm{~N} \mathrm{HCl}$ and $0.5 \mathrm{~N} \mathrm{NaOH}$ in such a manner that it has given a drug concentration of $1 \mathrm{mg} / \mathrm{mL}$, to study the effect of acid and alkali medium. Similarly, drug concentration of $1 \mathrm{mg} / \mathrm{mL}$ in $3 \% \mathrm{H}_{2} \mathrm{O}_{2}$ solution was used to study effect of peroxide on drug. All the prepared solutions were stored at room temperature for $24 \mathrm{hr}$. Set of samples 
also stored under dark and faced similar stress condition as stored under normal condition.

\section{Method validation}

\section{Preparation of standard stock solutions and dilution} scheme

$25 \mathrm{mg}$ of TOR was accurately weighed and transferred into $25 \mathrm{~mL}$ volumetric flask and made up with mobile phase. From this take $5 \mathrm{~mL}$ above solution and added $25 \mathrm{mg}$ of SPI was accurately weighed than transferred into $25 \mathrm{~mL}$ volumetric flask and made up with mobile phase $(200 \mu \mathrm{g} /$ $\mathrm{mL}$ TOR and $1000 \mu \mathrm{g} / \mathrm{mL}$ SPI). From this take $5 \mathrm{~mL}$ of above solution and transferred into $25 \mathrm{~mL}$ of volumetric flask and made up with mobile phase $(40 \mu \mathrm{g} / \mathrm{mL}$ TOR and $200 \mu \mathrm{g} / \mathrm{mL}$ SPI) For that pipette out 0.5, 1,1.5, 2,2.5,3 mL of solution and transferred in a same series of $10 \mathrm{~mL}$ volumetric flasks and diluted up to mark with mobile phase (2-12 $\mu \mathrm{g} / \mathrm{mL}$ TOR and 10-60 $\mu \mathrm{g} / \mathrm{mL}$ SPI)

\section{Procedure for estimation of TOR and SPI in tablet}

$25 \mathrm{mg}$ of Dytor plus tablet was taken into $25 \mathrm{~mL}$ volumetric flask and dilute up to the mark with buffer/ACN to get a concentration of $100 \mu \mathrm{g} / \mathrm{mL}$ TOR and SPI. From this $0.6 \mathrm{~mL}$ was taken and diluted to $10 \mathrm{~mL}$ to get a concentration of $6 \mu \mathrm{g} / \mathrm{mL}$ and $30 \mu \mathrm{g} / \mathrm{mL}$ of TOR and SPI respectively.

\section{Validation of the proposed method}

International Conference on Harmonization (ICH) guidelines Q2R1 [60] were used to validate the proposed method.

\section{Linearity}

Linearity was observed in a concentration range of $2-$ $12 \mu \mathrm{g} / \mathrm{mL}$ for TOR \& $10-60 \mu \mathrm{g} / \mathrm{mL}$ for SPI. The linearity graph of peak area was plotted against concentrations.

\section{Precision (repeatability)}

The precision of the method was checked by repeating six solutions TOR $(4 \mu \mathrm{g} / \mathrm{mL})$ for SPI $(20 \mu \mathrm{g} / \mathrm{mL})$ and measured the peak area without changing the parameter of the proposed method. The precision of method was reported in terms of mean, standard deviation and relative standard deviation (\% RSD).

\section{Intermediate precision}

The intra-day and inter-day precision of the proposed method was done by analyzing the corresponding responses three times on the same day and on three different days for three different concentrations over the calibration range of TOR $(2,4$ and $8 \mu \mathrm{g} / \mathrm{mL})$ \& SPI $(10,20$ and $30 \mu \mathrm{g} / \mathrm{mL}$ ). The results were reported in terms of relative standard deviation (\%RSD).

\section{Accuracy (recovery study)}

The known quantity of standard TOR \& SPI were added to the sample and the recovery of the standard from the same were calculated as \% recovery. Known amounts of standard solutions of TOR \& SPI were added at 80, 100 and $120 \%$ level to pre-quantified sample solutions of TOR \& SPI $(4 \mu \mathrm{g} / \mathrm{mL}$ and $20 \mu \mathrm{g} / \mathrm{mL})$.

\section{Limit of detection and limit of quantification}

LOD and LOQ were calculated by using following equations.

$$
\begin{aligned}
& \mathrm{LOD}=3.3 \times \sigma / \mathrm{S} \\
& \mathrm{LOQ}=10 \times \sigma / \mathrm{S}
\end{aligned}
$$

Where, $\sigma=$ the standard deviation of the response $\mathrm{S}=$ slope of the calibration curve

\section{Robustness}

Robustness has to studied by analyzing the samples of TOR \& SPI by deliberate variation in the method parameters. For that $\mathrm{QbD}$ approach was applied to determine the robustness (discuss in following section).

\section{Development and validation of torsemide and spironolac- tone by HPLC method using QbD approach [61]}

\section{Preparation of stock solution of TOR and SPI}

$25 \mathrm{mg}$ of TOR and SPI was accurately weighed and transferred into different $25 \mathrm{~mL}$ volumetric flasks and volume was made up with mobile phase $(1000 \mu \mathrm{g} / \mathrm{mL})$. From this $1 \mathrm{~mL}$ of resulting solutions diluted to $10 \mathrm{~mL}$ in volumetric flasks using mobile phase $(100 \mu \mathrm{g} / \mathrm{mL})$.

\section{Factorial design}

Two-level design with 3 factor i. e., pH, \% Composition and Flow rate at 2 different levels was studied as shown in Table 1 (1 and -1)

\section{Experimental runs}

As per the design, we have determined the best possibility for experiments that required 8 runs as mentioned in Table 2: 
Table 1: 2 level 3 factorial design.

\begin{tabular}{lrrr}
\hline Level & r & Factor \\
\cline { 2 - 4 } & pH & $\begin{array}{r}\text { Composition } \\
\text { of mobile phase (\%v/v) }\end{array}$ & $\begin{array}{r}\text { Flow rate } \\
(\mathrm{mL} / \mathrm{min})\end{array}$ \\
\hline-1 & 4 & $5: 3: 2(\mathrm{ACN}: \mathrm{MeOH}:$ Water) & 0.8 \\
1 & 5 & $4: 3: 3$ (ACN:MeOH:Water) & 1.0 \\
\hline
\end{tabular}

Table 2: Experimental runs.

\begin{tabular}{lcrr}
\hline Sr No. & pH & $\begin{array}{r}\text { Composition of mobile } \\
\text { phase }(\% \mathrm{v} / \mathrm{v})\end{array}$ & $\begin{array}{r}\text { Flow rate } \\
(\mathrm{mL} / \mathrm{min})\end{array}$ \\
\hline 1 & 4 & $5: 3: 2$ & 0.8 \\
2 & 4 & $5: 3: 2$ & 1.0 \\
3 & 4 & $4: 3: 3$ & 0.8 \\
4 & 4 & $4: 3: 3$ & 1.0 \\
5 & 5 & $5: 3: 2$ & 0.8 \\
6 & 5 & $5: 3: 2$ & 1.0 \\
7 & 5 & $4: 3: 3$ & 0.8 \\
8 & 5 & $4: 3: 3$ & 1.0 \\
\hline
\end{tabular}

\section{Characterization of degradation product(s)}

LC-MS studies were carried out to determine $\mathrm{m} / \mathrm{z}$ values of the major degradation products formed under various stress test conditions. The obtained values were compared with the mass spectrum of known degradation products of TOR and SPI.

\section{Results and discussion}

The goal of this work was to provide an accurate selective simultaneous estimation method for identification and determination of the TOR and SPI and related substance by LC-MS Acetonitrile: Methanol: Water $(5: 3: 2 \mathrm{v} / \mathrm{v} / \mathrm{v})$ as a mobile phase in the LC/MS work.

\section{Selection of mobile phase}

For the selection of mobile phase, we have varied the concentration of mobile phase Methanol and Acetonitrile with the addition of water ranging from $10 \%$ to $90 \%$ at a flow rates ranging from $0.1-1.0 \mathrm{~mL} / \mathrm{min}$ chromatograms were recorded.

Amongst the all result obtained, the optimized system containing Acetonitrile: Methanol: Water (5:3:2 $\mathrm{v} / \mathrm{v} / \mathrm{v}$ ) at $0.2 \mathrm{~mL} / \mathrm{min}$, was found to be satisfactory and gave well separate peak for TOR and SPI (Figure 2).

\section{Degradation studies}

Under the different condition of stress degradation, three degradant of TOR and one degradant of SPI were separated and identified (Figure 3). The retention time and relative retention time (RRT) of the drug and degraded products are shown in Table 3.

\section{Stress degradation by hydrolysis under acidic condition and basic conditions}

The TOR degraded with given acidic condition $(0.5 \mathrm{~N} \mathrm{HCl}$, $24 \mathrm{hrs}$ ) with time and gave three degradation peak at RRT (w.r.t. TOR) 2.25, 3.1 and 3.2 respectively. While SPI under the same acidic condition gave one degradation peak at RRT (w.r.t. SPI) 1.55.

Similarly, under the imparted alkali condition $(0.5 \mathrm{~N}$ $\mathrm{NaOH}, 24$ hrs.), TOR degraded with time and gave two peaks at RRT 1.35 and 2.25. There was degradation of SPI $(21.7 \%)$ found in the alkali condition but no degradation peak observed in chromatogram. This may be due to the non UV absorbent fragment was removed from the structure.

The results show that both TOR and SPI are sensitive to the acidic as well as basic conditions.

\section{Oxidative degradation and hydrolysis}

Exposing the TOR and SPI to the oxidative conditions ( $3 \% \mathrm{H}_{2} \mathrm{O}_{2}, 24 \mathrm{hrs}$.), It was observed that both the drug degrade in oxidative condition and one major degradant of TOR was observed at RRT 1.35 (w.r.t. TOR).

Similarly, when TOR and SPI bring out in contact with water (24 hrs.), they remain stable and not degraded. Hence, results reveal that both drugs are sensitive to oxidation while quite stable under hydrolysis condition.

\section{Validation of the developed method}

\section{Linearity}

The linearity study was carried out for both drugs at six different concentration levels. For the linearity study 


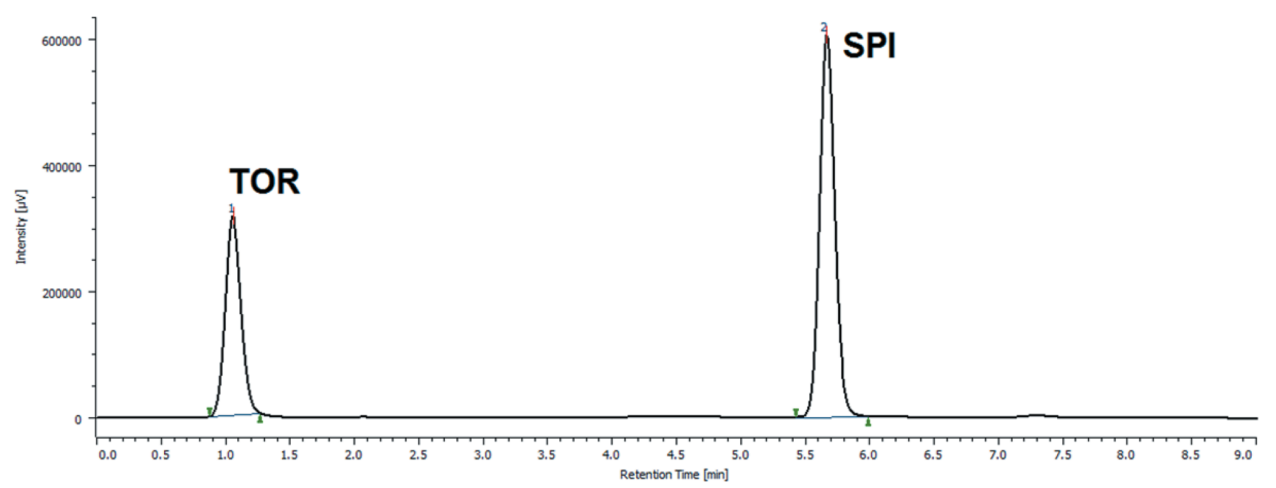

Figure 2: Chromatogram of standard TOR and SPI.
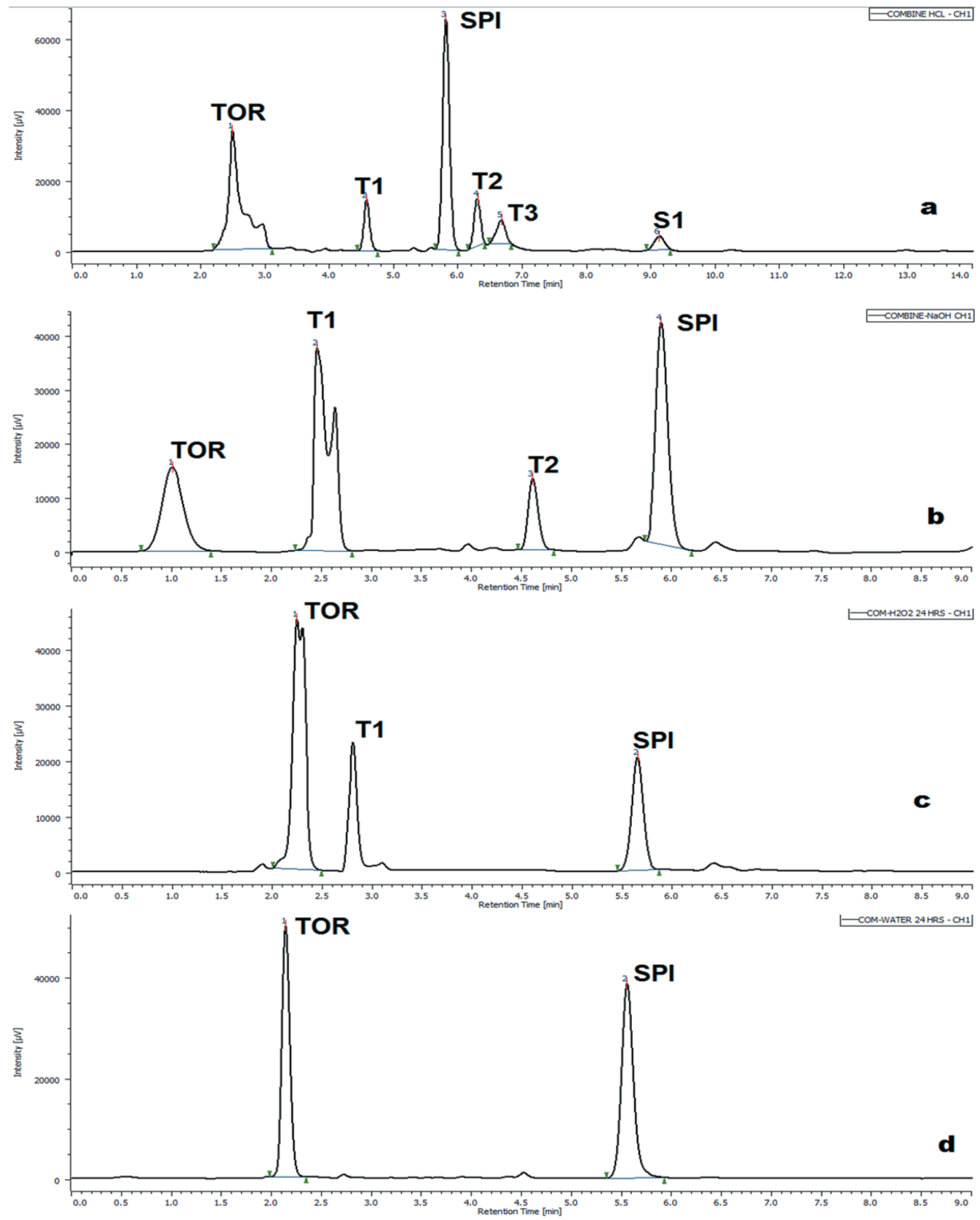

Figure 3: Chromatogram for (a) Acid degradation (b) Alkali degradation (c) Oxidative degradation and (d) Water degradation of TOR and SPI. 
Table 3: Result of Stress degradation study for TOR \& SPI.

\begin{tabular}{|c|c|c|c|c|c|}
\hline Drug & Condition & Time (Hour) & $\%$ Degradation & Degradants peaks & RRT \\
\hline \multirow[t]{4}{*}{ LOR } & $0.5 \mathrm{~N} \mathrm{HCL}$ & 24 & 32.9 & 3 Peak (T1, T2, T3) & $2.25,3.1,3.2$ \\
\hline & $0.5 \mathrm{~N} \mathrm{NaOH}$ & 24 & 27.5 & 2 Peak $(\mathrm{T} 1, \mathrm{~T} 2)$ & $1.35,2.25$ \\
\hline & Oxidative degradation & 24 & 20.7 & 1 Peak (T1) & 1.35 \\
\hline & Water degradation & 24 & 1.8 & No Peak & - \\
\hline \multirow[t]{4}{*}{ SPI } & $0.5 \mathrm{~N} \mathrm{HCL}$ & 24 & 23.7 & 1 Peak (S1) & 1.55 \\
\hline & $0.5 \mathrm{~N} \mathrm{NaOH}$ & 24 & 21.7 & No Peak & - \\
\hline & Oxidative degradation & 24 & 21.0 & No Peak & - \\
\hline & Water degradation & 24 & 1.6 & No Peak & - \\
\hline
\end{tabular}

Table 4: Linearity data of TOR.

\begin{tabular}{|c|c|c|c|c|c|c|}
\hline Sr No. & Conc. of TOR $(\mu \mathrm{g} / \mathrm{mL})$ & Conc. of SPI $(\mu \mathrm{g} / \mathrm{mL})$ & Area TOR $($ Mean \pm SD) & CV & Area SPI $($ Mean \pm SD*) & CV \\
\hline 1 & 2 & 10 & $12,539 \pm 103$ & 0.82 & $86,875 \pm 154$ & 0.18 \\
\hline 2 & 4 & 20 & $24,884 \pm 196$ & 0.79 & $158,292 \pm 832$ & 0.53 \\
\hline 3 & 6 & 30 & $37,106 \pm 145$ & 0.39 & $269,568 \pm 906$ & 0.34 \\
\hline 4 & 8 & 40 & $50,131 \pm 455$ & 0.91 & $345,164 \pm 1252$ & 0.36 \\
\hline 5 & 10 & 50 & $64,572 \pm 574$ & 0.89 & $439,528 \pm 1367$ & 0.31 \\
\hline 6 & 12 & 60 & $80,264 \pm 614$ & 0.76 & $532,539 \pm 2264$ & 0.43 \\
\hline
\end{tabular}

of TOR and SPI, concentration range of $2-12 \mu \mathrm{g} / \mathrm{mL} \& 10-$ $60 \mu \mathrm{g} / \mathrm{mL}$ was selected.

The data of the peak areas obtained with the respective concentrations in $\mu \mathrm{g} / \mathrm{mL}$ are shown in Table 4 for TOR \& SPI. The calibration curves for TOR \& SPI are shown in Figure 4.
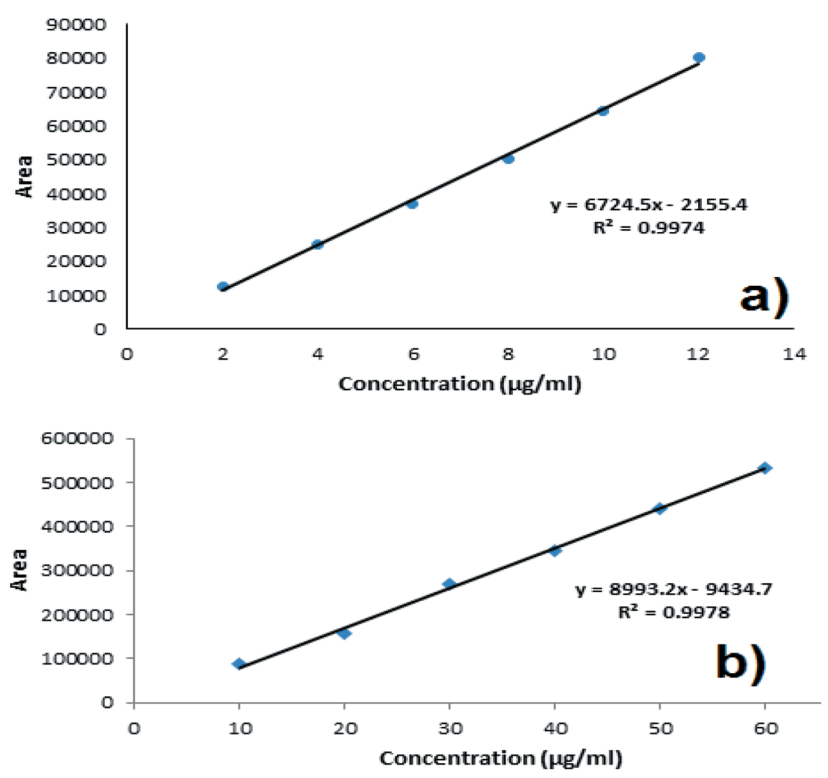

Figure 4: Calibration curve of (a) LOR (b) SPI in proposed mobile phase.

\section{Accuracy (recovery)}

Accuracy of method was determined by standard addition at three different concentrations levels i. e. $80 \%$, $100 \%$ and $120 \%$ to the pre-analyzed sample of the drugs $4 \mu \mathrm{g} / \mathrm{mL}$ and $20 \mu \mathrm{g} / \mathrm{mL}$ and each results was average of three determinations. The results of recovery study for TOR and SPI are shown in Table 5.

\section{Precision}

The value of \% RSD for TOR for intra-day precision and inter-day were found to be in the range 0.43 to 0.64 of $\%$ and 0.38 to $0.88 \%$ respectively which indicated that the method was precise.

The value of \% RSD for SPI for intra-day precision and inter-day were found tobe in the range of 0.03 to $0.53 \%$ and 0.20 to $1.07 \%$ respectively as shown in Table 6 which indicated that the method was precise.

\section{Robustness}

The robustness of the method checked by the QbD approach and experimentation done as per Table 2 and found that when changed in essential parameter, results remains unaffected (Table 7). 
Table 5: Result of Recovery study.

\begin{tabular}{lrrrrrr}
\hline Drug & Conc. level (\%) & Amount taken $(\mu \mathrm{g} / \mathrm{mL})$ & Amount added $(\mu \mathrm{g} / \mathrm{mL})$ & Total amount $(\mu \mathrm{g} / \mathrm{mL})$ & \%Recovered Mean \pm SD* & CV \\
\hline TOR & $80 \%$ & 4 & 2 & 6 & $98.55 \pm 0.67$ & 0.68 \\
& $100 \%$ & 4 & 4 & 8 & $99.67 \pm 0.52$ & 0.52 \\
& $120 \%$ & 4 & 8 & 10 & $99.05 \pm 0.15$ & 0.14 \\
SPI & $80 \%$ & 20 & 10 & 30 & $98.82 \pm 1.36$ & 1.37 \\
& $100 \%$ & 20 & 20 & 40 & $98.09 \pm 0.27$ & 0.28 \\
& $120 \%$ & 30 & 50 & $100.01 \pm 0.60$ & 0.60 \\
\hline
\end{tabular}

Table 6: Result of precision study.

\begin{tabular}{|c|c|c|c|c|c|c|c|}
\hline \multirow[t]{2}{*}{ Drug } & \multirow[t]{2}{*}{ Parameters } & \multicolumn{3}{|c|}{ Intraday precision concentration $(\mu \mathrm{g} / \mathrm{mL})$} & \multicolumn{3}{|c|}{ Inter day precision concentration $(\mu \mathrm{g} / \mathrm{mL})$} \\
\hline & & 2 & 4 & 8 & 2 & 4 & 8 \\
\hline \multirow[t]{3}{*}{ TOR } & Mean area & 12,404 & 25,008 & 50,319 & 12,303 & 24,996 & 50,643 \\
\hline & S.D* & 98 & 108 & 260 & 84 & 97 & 446 \\
\hline & CV & 0.79 & 0.43 & 0.52 & 0.68 & 0.38 & 0.88 \\
\hline \multirow[t]{3}{*}{ SPI } & Mean & 87,402 & 158,501 & 268,847 & 86,803 & 158,612 & 269,211 \\
\hline & S.D & 470 & 501 & 883 & 530 & 642 & 914 \\
\hline & CV & 0.53 & 0.32 & 0.33 & 0.61 & 0.41 & 0.34 \\
\hline
\end{tabular}

Table 7: Result of robustness study by QbD.

\begin{tabular}{lrrrrrr}
\hline Sr No. & pH & $\begin{array}{r}\text { Composition of mobile } \\
\text { phase }(\% / / v)\end{array}$ & $\begin{array}{r}\text { Flow rate } \\
(\mathrm{mL} / \mathrm{min})\end{array}$ & $\begin{array}{r}\text { \%Recovered (TOR) } \\
\text { Mean } \pm \text { SD* }\end{array}$ & $\begin{array}{r}\text { CV } \\
\text { \%Recovered (SPI) } \\
\text { Mean } \pm \text { SD* }\end{array}$ \\
\hline 1 & 4 & $5: 3: 2$ & 0.8 & $99.14 \pm 0.26$ & 0.26 & $98.89 \pm 0.74$ \\
2 & 4 & $5: 3: 2$ & 1.0 & $100.37 \pm 0.52$ & 0.51 & $99.67 \pm 0.52$ \\
3 & 4 & $4: 3: 3$ & 0.8 & $99.05 \pm 0.15$ & 0.14 & $99.05 \pm 0.15$ \\
4 & 4 & $4: 3: 3$ & 1.0 & $98.82 \pm 1.36$ & 1.37 & $98.82 \pm 1.36$ \\
5 & 5 & $5: 3: 2$ & 0.8 & $98.09 \pm 0.27$ & 0.28 & $98.09 \pm 0.27$ \\
6 & 5 & $5: 3: 2$ & 1.0 & $100.01 \pm 0.60$ & 0.60 & $100.01 \pm 0.60$ \\
7 & 5 & $4: 3: 3$ & 0.8 & $98.55 \pm 0.67$ & 0.68 & $98.55 \pm 0.67$ \\
8 & 5 & $4: 3: 3$ & 1.0 & $99.67 \pm 0.52$ & 0.52 & 9.60 \\
\hline
\end{tabular}

\section{Limit of detection and limit of quantification}

The limit of detection and limit of quantification for TOR \& SPI were calculated theoretically and found to be 10 and $33 \mathrm{ng}$ for TOR and 75 and $248 \mathrm{ng}$ for SPI respectively.

\section{Statistical comparison of the developed method}

\section{Comparison of RP- HPLC method for TOR and SPI by pair t- test}

The Assay result for TOR and SPI in tablet dosage form obtained using RP-HPLC method was compared statistically by applying two tail pair t-Test. The calculated $\mathrm{t}$-Value for TOR (0.78) and SPI (0.03) was less than tabulated t-Value at 95\% confidence interval (Table 8).

There for no significant difference were found in the content of TOR and SPI determined by proposed RP-HPLC method.

\section{Characterization of degradation products}

Mass chromatograms in the positive electron spray ionization (ESI) mode for the drug and degradation products are shown in Figure 5. The probable structures and observed mass of impurities identified in mass spectrometer are tabulated in Table 9. 
Table 8: Comparison of Methods for TOR and SPI.

\begin{tabular}{|c|c|c|c|c|}
\hline \multirow[t]{2}{*}{ Parameter } & \multirow[b]{2}{*}{ Reported } & \multirow[b]{2}{*}{ Experimental } & \multirow[b]{2}{*}{ Reported } & \multirow[b]{2}{*}{ Experimental } \\
\hline & & & & \\
\hline \multirow[t]{3}{*}{$\%$ Assay } & 99.96 & 101.00 & 99.90 & 103.00 \\
\hline & 99.94 & 99.30 & 99.95 & 101.66 \\
\hline & 99.90 & 99.96 & 99.87 & 102.02 \\
\hline Tabulated t-value & & 4.30 & & 4.30 \\
\hline Calculated t-value & & 0.78 & & 0.03 \\
\hline
\end{tabular}

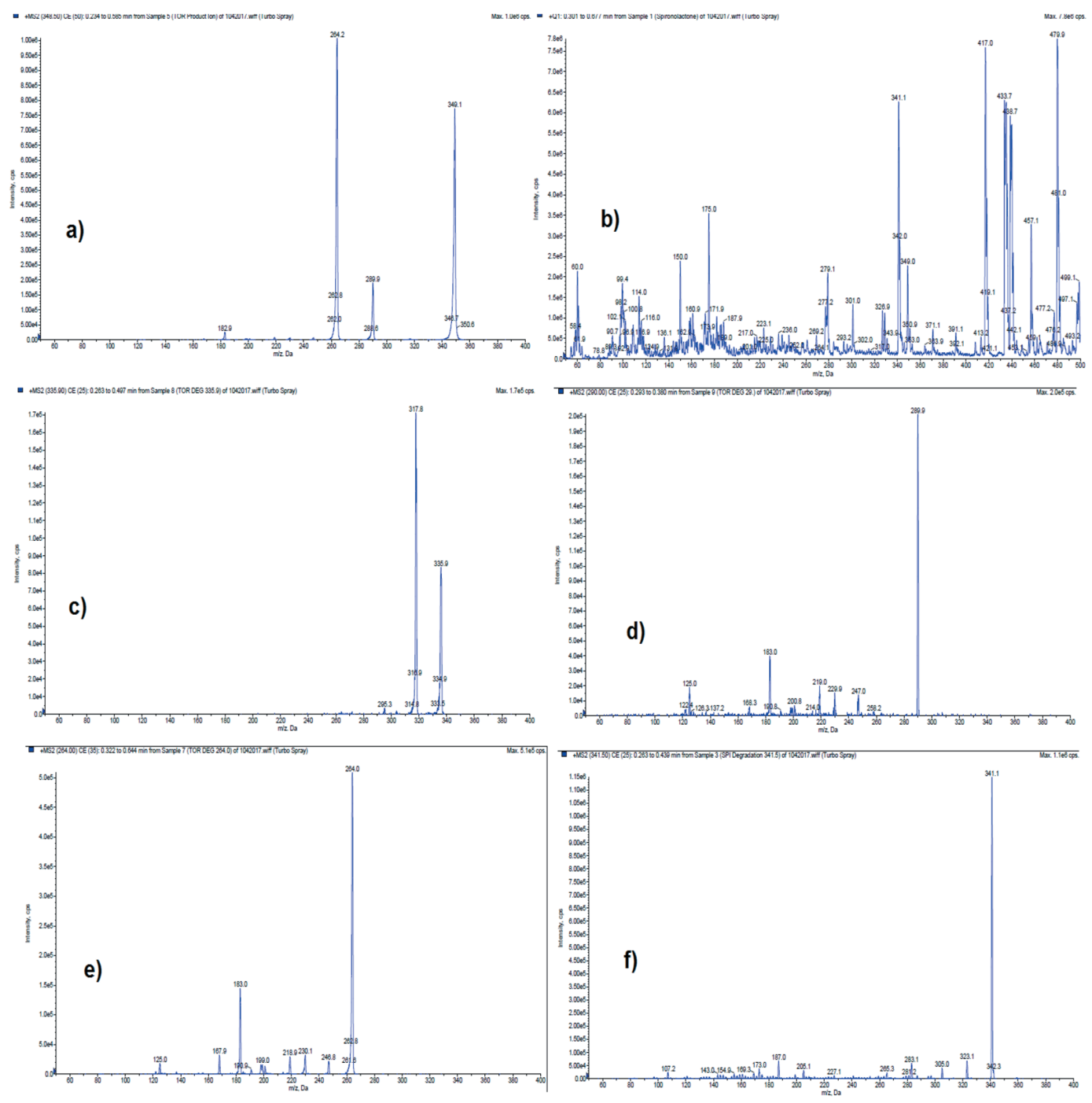

Figure 5: Mass Spectra of (a) Torsemide (b) Spironolactone (c) Impurity of a Torsemide at RRT 3.2 (1-ethyl-3-\{[4-[(3-methylphenyl)amino] pyridine-3-yl]sulphonyl\}urea (d) Impurity of a Torsemide at RRT 3.1 (4-(3-Methylphenyl)-2H-pyrido[4,3-e]-1, 2, 4-thiadiazin-3(4H)-one 1,1Dioxide) (e) Impurity of a Torsemide at RRT 2.25 (4-[(3-methylphenyl)amino]pyridine-3-sulphonamide) (f) Impurity of a Spironolactone at RRT 1.55 (Canrenone).

Evidently, the molecular weight of Torsemide (348.42) was obtained at $\mathrm{m} / \mathrm{z} 349.0(\mathrm{M}+\mathrm{H})$ and molecular weight of Spironolactone (416.57) was seen at $\mathrm{m} / \mathrm{z} 417.0(\mathrm{M}+\mathrm{H})$, thus validating the output of the mass spectrometer. The $\mathrm{m} / \mathrm{z}$ values obtained for the degradation products resolving at RRT 2.25, 3.1, 3.2 and 1.55 in the same run were 
Table 9: Probable structure and molecular mass of observed Impurities.

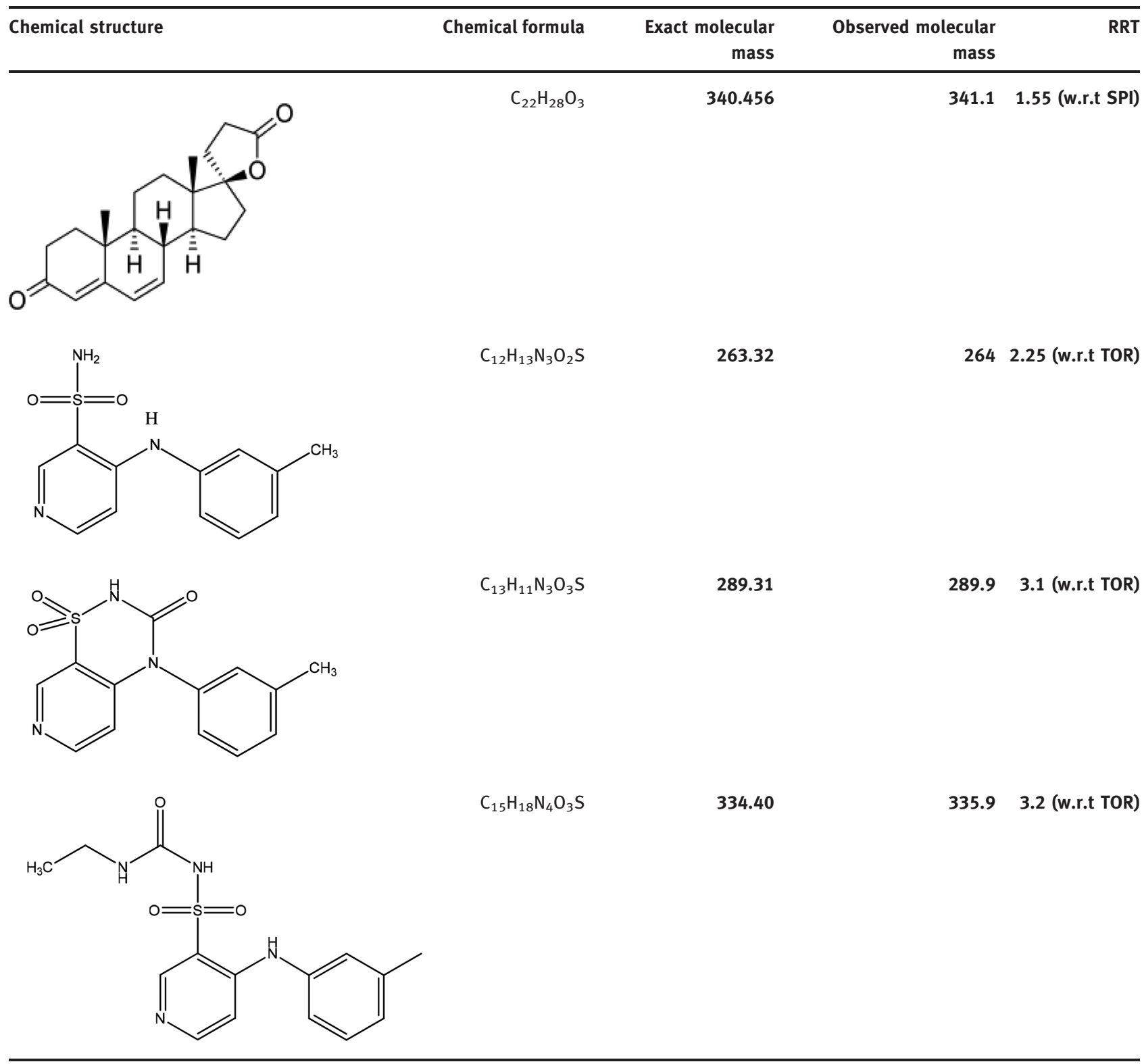

264, 289.9, 335.9 and 341.1 respectively. These were compared to the mass spectrum of known degradation products of TOR and SPI.

The m/z 264 at RRT 2.25 was observed might be due to the cleavage of $\mathrm{NH}-\mathrm{CO}$ bond next to the $\mathrm{SO}_{2}-\mathrm{NH}$ bond. M/z 183.0 was found to be the most prominent fragment ion (Figure 5). Impurity $\mathrm{m} / \mathrm{z} 289.9$ was corresponds to RRT 3.1 and detected might due to the ring formation of $\mathrm{SO}_{2}$ and $\mathrm{NH}-\mathrm{CO}$ bond and cleavage of the $\mathrm{NH}-\left(\mathrm{CH}_{3}\right)_{2}$. Mass spectra of m/z 335.9 at RRT 3.2 was observed due to the branch cleavage at $\mathrm{C}-\mathrm{C}$ bond, results in removal of methylene group. The $\mathrm{m} / \mathrm{z} 341.1$ at
RRT 1.55 was observed due to the cleavage of $\mathrm{C}-\mathrm{S}$ bond in spironolactone.

\section{Conclusion}

To the best of our knowledge this is the first method that utilised for the simultaneous determination of Torsemide and Spironolactone and related compound by stress degradation by QbD with LC-MS approach. Torsemide and Spironolactone are susceptible to the acid, base and oxidative degradation while they are stable when exposed 
to water. The use of $\mathrm{QbD}$ approach confirmed the robustness of the method. The LC-MS method successfully separates and identifies the LOR and SPI in formulations and also separates degradant impurities simultaneously.

Research funding: This study was completed with support of the Institute of Research and Development and without funding by other funding agencies.

Conflict of interest statement: The authors state no conflict of interest. The authors have read the journal's Publication ethics and publication malpractice statement available at the journal's website and hereby confirm that they comply with all its parts applicable to the present scientific work.

\section{References}

1. Brunton LL, Lazo JS, Parke KL. Goodman and Gilman's the pharmacological basis of therapeutics. 11th ed. New York: McGraw Hill Publishers, 2006:736-66.

2. Guptaa J, Kanojiaa G, Yadava V, Wakode R. Development and validation of a UV spectrophotometric method for the estimation of torsemide in bulk and in tablet dosage form. J Chem Pharm Res 2010;2:513-7.

3. Khalid M, Abasawy M, Rady A. Stability-indicating spectrophotometric methods for determination of torsemide in pure form and pharmaceutical preparation. Eur J Biomed Pharm Sci 2015;2:85-102.

4. Vamsi K, Gowri D. Simple spectrophotometric determination of torsemide in bulk drug and in formulations. E-Journal Chem 2008;5:473-8.

5. Bhadja S, Chhalotiya U, Shah D, Mehta F, Bhatt K. Simultaneous estimation of torsemide and amiloride hydrochloride in their pharmaceutical dosage form by dual wavelength UV spectroscopic method. Adv J Pharm Life Sci Res 2014;2:21-8.

6. Patel G, Patel H. Simultaneous determination of amiloride hydrochloride and torsemide in combined pharmacetical dosage form using spectrophotometric methods. World J Pharm Pharm Sci 2014;3:1351-60.

7. Patel R, Maheshwari D. Dual wavelength spectrophotometric method for simultaneous estimation of torsemide and amiloride hydrochloride in their combined dosage form. Scholars Res Lib, Der Pharmacia Lettre 2014;6:43-9.

8. Maheshwari D, Patel R. Absorption correction spectrophotometric method for simultaneous estimation of torsemide and amiloride hydrochloride in their combined dosage form. Pharmatutor 2014;2:123-31.

9. United States pharmacopoeia 30 national formulary 25, Asian ed. The official compendia of standards, United States Pharmacopeial Convention, Rockville, Md. 2007:3593-776.

10. Vasantha K, Sai Sree M, Lakshmi Suneetha G, Buchi N. Analysis of torsemide in bulk, dosage forms and dissolution samples using RP-HPLC-PDA method. J Chem Pharm Res 2014;6:334-40.

11. Thulasamma P, Venkateswarlu P. Development and validation of RP-HPLC method for the quantitative estimation of torsemide in pharmaceutical dosage forms and human serum. Int J ChemTech Res 2014;6:1103-9.

12. Sharma K, Gupta Sharma Y Method development and its validation for estimation of torsemide in tablet dosage form by RP. HPLC and UV spectrophotometry and comparison of two developed methods by using t-test. PHARMATUTOR-ART-1158.

13. Shukla R, Bhavsar N, Pandey V, Golhani D, Jain A. RP-HPLC determination of torsemide in pharmaceutical formulation by liquid chromatography. Asian J Biomed Pharm Sci 2012;2: 45-8.

14. Khan I, Loya P, Saraf M. A simplified HPLC method for quantification of torsemide from human plasma and its application to a bioequivalence study. Indian J Pharm Sci 2008;70:519-22.

15. Ghodke A, Poul B, Sorde M. Analytical method development and validation for quantitative estimation of torsemide in bulk and pharmaceutical dosage form by RP-HPLC. Int J Pharm Chem Anal 2014;1:6-13.

16. Zarko J, Zivanovic L, Radisic M, Protic A, Malesevic M. Chemometrically assisted development and validation of LC-UV and LC-MS methods for simultaneous determination of torsemide and its impurities. J Chromatogr Sci 2012;50:324-34.

17. Aragon A, Navoni J, Mcontartese C, Villagra A, Lopez C, Lepori E. Quantitative analysis of torsemide in human plasma by high performance liquid chromatography with ultraviolet detection. Rev Mex Patol Clin 2011;58:195-200.

18. Bhalodiya K, Modiya D, Faldu S. Analytical method development and validation for simultaneous estimation of amiloride and torsemide in their combined pharmaceutical dosage form by RP-HPLC method. PharmaTutor 2014;2:135-41.

19. Patel R, Maheshwari D. Rp-hplc method for the estimation of torsemide and amiloride $\mathrm{HCl}$ in their combined dosage form. Indo Am J Pharm Res 2014;4:2079-86.

20. Satasiya P, Chauhan P, Panchal I, Shah S (2014) RP-HPLC method development and validation for simultaneous estimation of amiloride hydrochloride and torsemide in tablet dosage form. Inventi:ppaqa/1410/14

21. Kakde R, Chaudhary N, Barsagade A, Kale D. Stability-indicating HPTLC method for analysis of torsemide in pharmaceutical preparations. Acta Chromatogr 2011;23:145-55.

22. Sharma K, Sharma Y, Goyal A Method development and its validation for estimation of spironolactone in tablet dosage form by UV spectrophotometry. PHARMATUTOR-ART-1139.

23. Indian Pharmacopoeia. Government of India, ministry of health and family welfare, vol. ume III. Ghaziabad: Published by The Indian Pharmacopoeia commission, 2014:2784-5.

24. British Pharmacopoeia. The Department of health, social services and public safety, vol. ume III. London: Published by Stationary office on behalf of MHRA, 2009:2928-9.

25. Rahul CR, Patel J, Bapna M. Development and validation of analytical method for estimation of spironolactone in oral suspension. J Chem Biol Phys Sci 2014;4:2196-204.

26. Gorzata M, Owy D, Pyka A. Lipophilicity assessment of spironolactone by means of reversed phase liquid chromatography and by newly developed calculation procedures. Acta Poloniae Pharm Drug Res 2015;72:235-44. 
27. Dong H, Xu F, Zhang Z, Tian Y, Chen Y. Simultaneous determination of spironolactone and its active metabolite canrenone in human plasma by HPLC-APCI-MS. J Mass Spectrom 2006;41:477-86.

28. Vadloori C, Venkat T. Development and validation of RP-HPLC method for simultaneous estimation of spironolactone and frusemide in bulk and pharmaceutical dosage forms. J Pharm Res 2012;5:3998-4000.

29. Walash M, Enany N, Eid M, Fathy M. Simultaneous determination of metolazone and spironolactone in raw materials, combined tablets and human urine by high performance liquid chromatography. Anal Meth 2013;5:5644-56.

30. Ram V, Dave P, Joshi H. Development and validation of a stability-indicating HPLC assay method for simultaneous determination of spironolactone and furosemide in tablet formulation. J Chromatogr Sci 2012;50:721-6.

31. Vlase L, Imre S, Muntean D, Achim M, Munteanb D. Determination of spironolactone and canrenone in human plasma by high-performance liquid chromatography with mass spectrometry detection. Croatica Chemica Acta 2011;84:361-6.

32. Siddartha B, Atma J. Simultaneous estimation and validation of metolazone and spironolactone in bulk and pharmaceutical dosage form by RP-HPLC method. Indo Am J Res 2014;4:5351-7.

33. Pallavi G, Kumar R. Analytical method development and validation of simultaneous estimation of metolazone and spironolactone in bulk and pharmaceutical dosage form by RP-HPLC. Indian J Res Pharm Biotechnol 2014;2: 1496-1500.

34. Tekerek E, Sukuroglu M, Atay O. Quantitative determination of hydrochlorothiazide and spironolactone in tablets by spectrophotometric and HPLC methods. Turk J Pharm Sci 2014;5: 53-66.

35. Sudhakarm D, Venkateshwara R. Isocratic RP-HPLC method for simultaneous estimation of spirinolactone and hydrochlorthiazide in oral solid dosage form. Res J Pharm Technol 2013;5:1050-3.

36. Bhojani M, Dadhania K, Faldu S. Development and validation of RP-HPLC method for simultaneous estimation of furosemide and spironolactone in their combined tablet dosage form. Journal Pharm Sci Bio Sci Res 2012;2:144-7.

37. Khanchandani L, Bhatt K, Shah D, Chhalotiya U. Simultaneous estimation of spironolactone and hydroflumethiazide in pharmaceutical dosage form by second order derivative UV- spectrophotometry method. Novus Int J Chem 2013;2:7-11.

38. Sayyed Z, Shinde S, Chaware V, Chaudhari B. Development and validation of UV- spectrophotometric method for simultaneous estimation of spironolactone and hydrochlorothiazide in pharmaceutical formulation. Journal Pharm Sci Bioscientific Res 2015;5:590-3.

39. Patel H, Solanki S. Development and validation of spectrophotometric methods for simultaneous estimation of furosemide and spironolactone in combined tablet dosage form. Int J Pharm Pharm Sci 2012;4:383-6.

40. Chaudhary A, Vadalia K, Thummer P. Development and validation of ratio derivative spectrophotometric for simultaneous estimation of metolazone and spironolactone in pharmaceutical dosage form. Int J Pharm Sci Res 2012;3:3999-4003.

41. Reddy A, Ahmed M, Shetty S. Simultaneous determination and validation of spironolactone and furosemide by second order derivative method and area under curve method in bulk drug and pharmaceutical formulations. Int J ChemTech Res 2013;5:1876-85.

42. Sayyed Z, Shinde S, Chaware V, Chaudhari B. Development and validation of UV- spectrophotometric method for simultaneous estimation of spironolactone and hydrochlorothiazide in pharmaceutical formulation. J Pharm Sci Bioscientific Res 2015;5:590-3.

43. Nazareth C, Kumar S, Reddy P, Gurupadayya B. Development and validation of HPTLC method for simultaneous estimation of metolazone and spironolactone in bulk drug and pharmaceutical dosage form. IOSR J Pharm 2014;4:20-5.

44. Kher G, Ram V, Kher M, Joshi H. Development and validation of a HPTLC method for simultaneous determination of furosemide and spironolactone in its tablet formulation. Res J Pharm Biol Chem Sci 2013;4:365-77.

45. Hegazy MA, Metwaly FH, Abdelkawy M, Abdelwahab NS. Validated chromatographic methods for determination of hydrochlorothiazide and spironolactone in pharmaceutical formulation in presence of impurities and degradants. Chromatogr Sci 2011;49:129-35.

46. Hegazy M, Metwaly F, Abdelkavy M, Abdelwaheb N. Validated chromatographic methods for determination of hydrochlorothiazide and spironolactone in pharmaceutical formulation in presence of impurities and degradants. J Chrometogr Sci 2011:49:129-35.

47. Ismail Y, Chandrasekhar K, Gunasekaran V. A new stability indicating hplc method development and validation for the simultaneous estimation of metolazone and spironolactone in bulk and in its pharmaceutical formulations. Int J Pharm Pharm Sci 2014;6:448-52.

48. Tekerek E, Sukuroglu M, Atay O. Dissolution tests of hydrochlorothiazide and spironolactone in commercial tablets: comparison of spectroscopic and high performance liquid chromatography methods. Fabad J Pharm Sci 2007;32:23-32.

49. Satyanarayana P, Adilakshmi G. RP-HPLC method development validation and forced degradation studies for simultaneous estimation of torsemide and spironolactone in tablet dosage form. Am J PharmTech Res 2015;5:625-37.

50. Laxman R, Acharya A, Jain V, Bhardwaj S. Development and validation of RP-HPLC and ultraviolet spectrophotometric methods for simultaneous determination of spironolactone and torsemide in pharmaceutical dosage form. Int Journal Res Ayurveda Pharm 2010;1:459-67.

51. Sharma S, Sharmab M, Kohlic D. Conventional and micellar liquid chromatography method with validation for torsemide and spironolactone in tablet combined dosage form. Der Pharmacia Lettre 2010;2:374-81.

52. Sharma S, Sharmab M, Kohlic D. Validated TLC densitometric method for the quantification of torsemide and spironolactone in bulk drug and in tablet dosage form. Der Pharma Chemica 2010;2:121-6.

53. Deshpande P, Gandhi S, Gaikwad N, Khandagle K. A simple and sensitive RP-HPLC method for simultaneous estimation of torsemide and spironolactone in combined tablet dosage form. Acta Chromatogr 2012;24:15-22.

54. Sharma K, Gupta SY. Spectrophotometric simultaneous estimation of spironolactone and torsemide in combined tablet dosage form using by multicomponent mode of analysis. PHARMATUTOR-ART-1180.

55. Gaikwad N, Deshpande P, Gandhi S, Khandagale K. High performance thin layer chromatographic determination of 
spironolactone and torsemide in combined tablet dosage form. Res J Pharm Technol 2010;3:1106-8.

56. Karbhari PA, Bhoir SI, Joshi SJ, Patel CB. A stability indicating LC method for simultaneous determination of torsemide, spironolactone and their related substances in tablet formulation. Anal Chem Indian J 2013;13:290-302.

57. Jovic Z, Zivanovic L, Protic A, Radisic M, Lausevic M, Malesevic M, et al. Forced degradation study of torasemide: characterization of its degradation products. J Liq Chromatogr Relat Technol 2013;36:2082-94.
58. Ich S Testing of new drug substances and products. International Conference on Harmonization, IFPMA, Geneva, 2003.

59. Blessy M, Patel RD, Prajapati PN, Agrawal YK. Development of forced degradation and stability indicating studies of drugs A review. J Pharm Anal 2014;4:159-65.

60. ICH, Validation of Analytical Procedures: text and Methodology. International Conference on Harmonization, IFPMA, Geneva, 2005.

61. ICH, Quality by design approach $\left[\mathrm{Q}_{8}\left(\mathrm{R}_{2}\right)\right]$. International Conference on Harmonization, 2009. 